\title{
PENGARUH HARGA, KUALITAS PRODUK DAN KUALITAS PELAYANAN TERHADAP KEPUASAN KONSUMEN PADA COFFEENATICS MEDAN
}

\author{
ANGGITA SINAGA \\ SARIMONANG SIHOMBING \\ DARNA SITANGGANG \\ Program Studi Manajemen Universitas Katholik Santo ThomasMedan \\ anggita_sinaga@gmail.com; sarimonangsihombing@gmail.com; darna.sitanggang@gmail.com
}

\begin{abstract}
ABSTRAK
Penelitian ini bertujuan untuk menguji secara empiris pengaruh harga, kualitas produk, dan kualitas pelayanan baik secara parsial maupun secara simultan terhadap kepuasan konsumen pada Coffeenatics Medan. Pengumpulan data dilakukan melalui penyebaran kuisioner terhadap konsumen yang berkunjung pada Coffeenatics Medan sebanyak 96 orang. Analisis data pada penelitian ini menggunakan regresi linier berganda. Dari hasil uji hipotesis secara parsial diperoleh nilai $\mathrm{P}$ value harga sebesar $0,000<\alpha(0,05)$, nilai $\mathrm{P}$ value kualitas produk $(0,022)<\alpha(0,05)$, nilai $\mathrm{P}$ value kualitas pelayanan $(0,047)<\alpha(0,05)$, berarti harga $\left(\mathrm{X}_{1}\right)$, kualitas produk $\left(\mathrm{X}_{2}\right)$ dan kualitas pelayanan $\left(\mathrm{X}_{3}\right)$ berpengaruh positif dan signifikan secara parsial terhadap kepuasan konsumen. Uji $\mathrm{F}$ menunjukkan bahwa nilai $\mathrm{p}$ value $(0,000)<\alpha(0,05)$ artinya bahwa variabel harga, kualitas produk,dan kualitas pelayanan berpengaruh signifikan terhadap kepuasan konsumen. Dari hasil pengolahan data dengan menggunakan SPSS, diperoleh persamaan regresi linear berganda: $\quad Y=5,086+0,608 X 1+0,254 X 2+0,244 X 3$ +ei. Berdasarkan persamaan regresi berganda tersebut dapat diketahui bahwa ketiga variabel bebas yaitu harga, kualitas produk dan kualitas pelayanan mempunyai pengaruh positif terhadap kepuasan konsumen, dan variabel harga mempunyai pengaruh yang lebih besar karena memiliki koefisien regresi paling besar yakni 0,608. Koefisien determinasi (R Square) sebesar 0,471, artinya variasi variabel kepuasan konsumen mampu dijelaskan variabel bebas (harga, kualitas produk dan kualitas pelayanan) sebesar $47,1 \%$ dan sisanya $56,9 \%$ dijelaskan oleh variabel lain yang tidak termasuk dalam penelitian ini seperti lokasi, promosi dan sebagainya
\end{abstract}

Kata kunci : Harga, Kualitas Produksi,Kualitas Pelayanan,Kepuasan Konsumen.

\section{PENDAHULUAN}

Penduduk Indonesia semakin padat dan semakin konsumtif dalam melakukan transaksi setiap tahunnya. Salah satu kegiatan konsumtif masyarakat saat ini seperti konsumsi makanan dan berkumpul di cafe. Disisi lain, terjadi pula perubahan pola gaya hidup seperti kebiasaan minum kopi di rumah, sekarang lebih memilih untuk minum kopi di tempat lain seperti cafe. Hal tersebut mendorong semakin meningkatnya 
kebutuhan akan tempat-tempat makan disertai dengan suasana yang mendukung untuk berkumpul bersama dengan relasi mereka.

Masyarakat yang berada di Sumatera Utara terutama di kota-kota besar seperti Medan memiliki tingkat konsumsi yang tinggi, contohnya dalam bidang cafe. Bisnis cafe yang semakin banyak membuat kondisi persaingan dalam industri tersebut menjadi ketat, sehingga dalam mendirikan usaha tersebut harus mampu memberikan layanan yang terbaik kepada pelanggan sehingga pelanggan merasa puas dan mau kembali ke cafe tersebut bahkan mau merekomendasikan kepada relasi mereka, dengan harapan cafe tersebut mampu bertahan, bersaing, dan menguasai pasar. Perubahan gaya hidup masyarakat ini sebenarnya bermula sejak munculnya Starbuck di Indonesia pada 17 Mei 2002. Starbuck memiliki visi bahwa Starbuck dapat dijadikan inspirasi atau contoh yang memberikan kenyamanan kepada pelanggan melalui produk yang disajikan bersama dengan lingkungan yang memberikan kesan mendalam, lingkungan kerja yangnyamandan tertib dimana perusahaan memberi fasilitasdengan peraturan yang fleksibel kepada karyawan untuk dapat menjadikan Starbuck tidak hanya sekedar tempat untuk bekerja saja namun juga sebagai rumah yang dapat membuat pelanggan merasa betah. Standar mutu yang tinggi, semua produk yang ditawarkan kepada pelanggan memiliki standar mutu yang telah ditetapkan dan menggunakan produk dengan nilai mutu tinggi untuk dapat memberikan produk terbaik kepada para pelanggan, ditambah layanan terbaik yang mampu diberikan oleh barista kepada para pelanggan.

Barista dituntut untuk selalu ramah dan dalam hal ini Starbuck menerapkan standar layanan yang dapat membuat pelanggan merasa betah dan menjadikan Starbuckss sebagai rumah ketiga bagi pelanggan. Starbuck lebih berfokus kepada masyarakat dengan kelas sosial menengah ke atas yang memiliki gaya hidup glamour, yang dalam kepribadiannya memnyukai sesuatu yang berbeda dan memiliki keinginanuntuk mendapatkan pengalaman minum kopi yang baik. Hal tersebut didukung oleh lokasi yang dipilih oleh Starbucks untuk membuka tokonya, yaitu pusat perbelanjaan (mall), kompleks perumahan, perkanturan, dan rest area, semakin tahun Starbuck semakin dikenal dan diminati oleh masyarakat Indonesia, Adanya fenomena ini memunculkan ide bagi para pebisnis untuk mendirikan sebuah usaha yang berorientasi pada kedai kopi atau cafe. 
Menurut Philip Kotler dan Gary Amstrong (2014), harga adalah jumlah uang yang ditagihkan atas suatu produk atau jasa. Lebih luas lagi, harga adalah jumlah semua nilai yang diberikan oleh pelanggan untuk mendapatkan

keuntungan dari memiliki atau menggunakan suatu produk atau jasa. Harga juga merupakan indikator nilai, karena berhubungan dengan manfaat langsung yang dirasakan oleh konsumen. Harga tergantung pada kebijakan perusahaan dengan mempertimbangkan berbagai hal. Murah atau mahalnya harga suatu produk atau jasa sangat relatif sifatnya. Perusahaan harus selalu memantau harga yang ditetapkan oleh pesaing agar harga yang ditentukan oleh perusahaan tersebut tidak terlalu tinggi atau terlalu rendah. Bagi konsumen harga sering dikaitkan dengan manfaat yang diperoleh atas suatu barang atau jasa. Pembeli menggunakan harga tidak hanya pada ukuran pengorbanan, tetapi juga digunakan sebagai indikator kualitas produk danlayanan.

Kualitas produk adalah faktor penentu kepuasan konsumen setelah melakukan pembelian dan pemakaian terhadap suatu produk. Dengan kualitas produk yang baik maka keinginan dan kenutuhan konsumen akan suatu produk akan terpenuhi. Menurut Albertus Ferry Rostya Adi (2012), kualitas produk adalah suatu kondisi dari suatu barang berdasarkan pada penilaian dan kesesuaiannya dengan standar ukur yang telah di tetapkan. Untuk mencapai kualitas produk yang diinginkan maka diperlukan standarisasi kualitas. Hal ini bertujuan untuk menjaga agar produk yang dihasilkan memenuhi standar yang telah ditetapkan sehingga konsumen tidak akan kehilangan kepercayan terhadap produk yang bersangkutan. Pengalaman konsumen dalam membeli produk yang baik atau buruk akan mempengaruhi konsumen untu melakukan pembelian kembali atau tidak. Oleh karena itu, pemasar harus mampu menciptakan produk yang sesuai dengan kebutuhan dan selerakonsumen.

Kualitas pelayanan merupakan salah satu faktor penting dalam meningkatkan daya saing. Harapan dari konsumen setiap saat selalu berubah sehingga kualitas pelayanan yang diberikan juga harus disesuaikan. Konsumen akan menilai pelayanan yang diberikan oleh suatu perusahaan dengan membandingkan dari perusahaan satu dengan perusahaan lain yang sejenis, juga dengan membandingkan pelayanan yang diterima dengan pelayanan yang diharapkannya.

Philip Kotler dan Armstrong (2014, p. 24), kepuasan pelanggan adalah tingkat perasaan seseorang setelah membandingkan kinerja (atau hasil) yang ia rasakan dibandingkan dengan harapannya. Fandi Tjiptono 
(2008) menyatakan dengan peraturan yang fleksibel kepada karyawan untuk dapat menjadikan Starbuck tidak hanya sekedar tempat untuk bekerja saja namun juga sebagai rumah yang dapat membuat pelanggan merasa betah. Standar mutu yang tinggi, semua produk yang ditawarkan kepada pelanggan memiliki standar mutu yang telah ditetapkan dan menggunakan produk dengan nilai mutu tinggi untuk dapat memberikan produk terbaik kepada para pelanggan, ditambah layanan terbaik yang mampu diberikan oleh barista kepada para pelanggan.

Barista dituntut untuk selalu ramah dan dalam hal ini Starbuck menerapkan standar layanan yang dapat membuat pelanggan merasa betah dan menjadikan Starbuckss sebagai rumah ketiga bagi pelanggan. Starbuck lebih berfokus kepada masyarakat dengan kelas sosial menengah ke atas yang memiliki gaya hidup glamour, yang dalam kepribadiannya memnyukai sesuatu yang berbeda dan memiliki keinginanuntuk mendapatkan pengalaman minum kopi yang baik. Hal tersebut didukung oleh lokasi yang dipilih oleh Starbucks untuk membuka tokonya, yaitu pusat perbelanjaan (mall), kompleks perumahan, perkanturan, dan rest area, semakin tahun Starbuck semakin dikenal dan diminati oleh masyarakat Indonesia, Adanya fenomena ini memunculkan ide bagi para pebisnis untuk mendirikan sebuah usaha yang berorientasi pada kedai kopi atau cafe.

Menurut Philip Kotler dan Gary Amstrong (2014), harga adalah jumlah uang yang ditagihkan atas suatu produk atau jasa. Lebih luas lagi, harga adalah jumlah semua nilai yang diberikan oleh pelanggan untuk mendapatkan

keuntungan dari memiliki atau menggunakan suatu produk atau jasa. Harga juga merupakan indikator nilai, karena berhubungan dengan manfaat langsung yang dirasakan oleh konsumen. Harga tergantung pada kebijakan perusahaan dengan mempertimbangkan berbagai hal. Murah atau mahalnya harga suatu produk atau jasa sangat relatif sifatnya. Perusahaan harus selalu memantau harga yang ditetapkan oleh pesaing agar harga yang ditentukan oleh perusahaan tersebut tidak terlalu tinggi atau terlalu rendah. Bagi konsumen harga sering dikaitkan dengan manfaat yang diperoleh atas suatu barang atau jasa. Pembeli menggunakan harga tidak hanya pada ukuran pengorbanan, tetapi juga digunakan sebagai indikator kualitas produk danlayanan.

Kualitas produk adalah faktor penentu kepuasan konsumen setelah melakukan pembelian dan pemakaian terhadap suatu produk. Dengan kualitas produk yang baik maka keinginan dan kenutuhan konsumen akan 
suatu produk akan terpenuhi. Menurut Albertus Ferry Rostya Adi (2012), kualitas produk adalah suatu kondisi dari suatu barang berdasarkan pada penilaian dan kesesuaiannya dengan standar ukur yang telah di tetapkan. Untuk mencapai kualitas produk yang diinginkan maka diperlukan standarisasi kualitas. Hal ini bertujuan untuk menjaga agar produk yang dihasilkan memenuhi standar yang telah ditetapkan sehingga konsumen tidak akan kehilangan kepercayan terhadap produk yang bersangkutan. Pengalaman konsumen dalam membeli produk yang baik atau buruk akan mempengaruhi konsumen untu melakukan pembelian kembali atau tidak. Oleh karena itu, pemasar harus mampu menciptakan produk yang sesuai dengan kebutuhan dan selerakonsumen.

Kualitas pelayanan merupakan salah satu faktor penting dalam meningkatkan daya saing. Harapan dari konsumen setiap saat selalu berubah sehingga kualitas pelayanan yang diberikan juga harus disesuaikan. Konsumen akan menilai pelayanan yang diberikan oleh suatu perusahaan dengan membandingkan dari perusahaan satu dengan perusahaan lain yang sejenis, juga dengan membandingkan pelayanan yang diterima dengan pelayanan yang diharapkannya.

Philip Kotler dan Armstrong (2014, p. 24), kepuasan pelanggan adalah tingkat perasaan seseorang setelah membandingkan kinerja (atau hasil) yang ia rasakan dibandingkan dengan harapannya. Fandi Tjiptono (2008) menyatakanbahwa kepuasan pelanggan merupakan suatu tanggapan emosional pada evaluasi terhadap pengalaman konsumsi suatu produk atau jasa. Kepuasan sendiri merupakan perasaan senang yang dialami oleh seseorang setelah menerima produk yang diinginkan dengan harga dan kualitas yang baik serta layanan yang memuaskan. Dengan memperhatikan aspek khususnya kepuasan pelanggan, maka kemungkinan untuk memperoleh competitive advantage akan semakinbesar.

Annisa Fiazisyah (2018) melakukan penelitian dengan judul "Pengaruh Kualitas Produk, Harga dan Kualitas Pelayanan Terhadap Kepuasan Konsumen Restoran Cepat Saji KFC Basuki Rahmat Surabaya. Hasil penelitian tersebut menunjukkan bahwa pengujian hipotesis secara serempak (ujiF) berpengaruh positif dan signifikan terhadap kepuasan konsumen yang terdiri dari variabel kualitas produk, harga dan, kualitas pelayanan pada Restoran Cepat Saji KFC Basuki Rahmat Surabaya. Hasil pengujian secara parsial (uji t)menunjukkan bahwa masing-masing variabel kualitas produk, harga dan, kualitas pelayanan mempunyai pengaruh positif dan signifikan terhadap terhadap kepuasan konsumen pada Restoran Cepat Saji KFC Basuki RahmatSurabaya. 
Rina Sukmawati (2017) melakukan penelitian dengan judul "Pengaruh Kualitas Produk, Harga, dan Pelayanan Terhadap Kepuasan Konsumen Garden Cafe Koperasi Mahasiswa Universitas Negeri Yogyakarta".Hasil penelitian tersebut menunjukkan bahwa pengujian hipotesis secara serempak (uji F) berpengaruh signifikan terhadap kepuasan konsumen dari variabel Kualitas produk, harga dan, kualitas pelayanan pada Garden Cafe Koperasi Mahasiswa Universitas Negeri Yogyakarta. Hasil pengujian secara parsial (uji t) menunjukkan bahwa masing-masing variabel kualiats produk, harga dan, kualitas pelayanan mempunyai opengaruh positif dan signifikan terhadap kepuasan pelanggan pada Garden Cafe Koperasi Mahasiswa Universitas Negeri Yogyakarta.

Coffeenatics adalah salah satu coffee shop yang bertempat di Jl. Teuku Cik Ditiro No. 8k Medan Polonia, kota Medan. Cafe ini menyediakan berbagai macam minuman yang berbau kopi, dan jugamakanan.Dengan semakin meningkatnya komsumtifitas dari masyarakat terutama dibidang kuliner mendorong Coffeenatics untuk menawarkan masyarakat khususnya kota medan produk dengan harga yang bersaing, kualitas yang baik, dengan kualitas pelayanan yang memuaskan.

Dalam memuaskan pelanggan, Coffeenatics Medan melakukan beberapacara antara lain:

- Pemesanan dilakukan secara langsung

- Ketersediaan lapanganparkir

- Ac

- wifi

- Ketersediaan private room

- Tersedia areamerokok

- Adanya layanan pesan antar

- Barista bersedia menjelaskan cara menyeduhkopi

- Kopi tersedia dari dalam dan luarnegeri

- Kopi di ambil langsung dari kebun oleh owner danBarista Adapun Café sejenis yang menjadi saingan dari Coffeenatics adalahDough and Coffee yang berada di Jl. Multatuli Blok FF No. 11 Kota Medan. Café ini juga menjual minuman dari olahan kopi, dan juga berbagai jenis makanan, yang beberapa menunya sama dengan menu yang terdapat padaCoffeenatics. 
Tabel 1. Perbandingan Daftar Harga Kopi dan Makanan di Coffeenatics dan Dough \&Coffee

\begin{tabular}{|c|l|c|l|c|}
\hline \multirow{2}{*}{ No } & \multicolumn{4}{|c|}{ Daftar Menu dan Harga Makanan dan Minuman } \\
\cline { 2 - 5 } & \multicolumn{1}{|c|}{ Coffeenatics } & Harga & \multicolumn{1}{c|}{ Dough \& Coffee } & Harga \\
\hline 1 & Espresso & 26.000 & Espresso & 21.000 \\
\hline 2 & Americano & 26.000 & Americano & 22.000 \\
\hline 3 & Piccolo Latte & 30.000 & Piccolo Latte & 25.000 \\
\hline 4 & Cappucino & 34.000 & Cappocino & 30.000 \\
\hline 6 & Mocha & 34.000 & Mocha & 40.000 \\
\hline 7 & Ice Caramel Latte & 39.000 & Ice Caramel Latte & 38.000 \\
\hline 7 & Fried Rice & 52.000 & Fried Rice & 35.000 \\
\hline 8 & Spaghetti Aglo Olio & 39.000 & Spaghetti Aglo Olio & 35.000 \\
\hline 9 & Chicken & 73.000 & Chicken & 45.000 \\
\hline & Rata-rata & $\mathbf{3 9 . 2 2 2}$ & Rata-rata & $\mathbf{3 2 . 3 3 3}$ \\
\hline
\end{tabular}

Sumber : Coffeenatics, Dough \& Coffee

Berdasarkan tabel 1. diatas dapat dilihat perbandingan harga antara Coffeenatics dengan Dough \& Coffee dengan rata-rata harga makanan danminuman Rp. 39.222, sedangkan pada Dough \& Coffee Rp. 32.333. Harga Kopi Coffeenatcs yang menjadi menu utama berkisar yaitu Espresso Rp. 26.000, sedangkan pada Dough \& Coffee harga kopi berkisar Rp. 21.000. Perbedaan harga juga terlihat pada harga makanan, pada Coffeenatics harga nasi goring Rp52.000 sedangkan pada Dough \& Coffee Rp. 35.000. Pebedaan harga ini akan mempengaruhi tingkat permintaan konsumen, dimana konsumen lebih dominan tertarik pada harga yang lebih murah.

Tabel 2. Data Penjualan Kopi pada Coffeenatics Medan pada bulan Mei 2018 - April 2019

\begin{tabular}{|l|c|}
\hline \multicolumn{1}{|c|}{ Bulan } & Terjual \\
\hline Mei 2018 & 2.520 Cup \\
\hline Juni 2018 & 2.397 Cup \\
\hline Juli 2018 & 1.960 Cup \\
\hline Agustus 2018 & 2.400 Cup \\
\hline September 2018 & 2.539 Cup \\
\hline Oktober 2018 & 1.166 Cup \\
\hline
\end{tabular}




\begin{tabular}{|l|l|}
\hline November 2018 & 1.200 Cup \\
\hline Desember 2018 & 3.000 Cup \\
\hline Januari 2019 & 2.561 Cup \\
\hline Februari 2019 & 4.040 Cup \\
\hline Maret 2019 & 3.000 Cup \\
\hline April 2019 & 3.118 Cup \\
\hline
\end{tabular}

Dari tabel 2 diketahui bahwa terjadi fluktuasi di setiap bulannya. Permasalahan yang menyebabkan terjadinya hal ini adalah karena adanya situasi dimana pada bulan-bulan tertentu terjadi pembelian yang cukup besar. Hal ini juga bisa disebabkan karena pada akhir tahun ini terdapat beberapa coffee shop baru yang berada di Sumatera utara khususnya di daerah kota Medan dan menawarkan harga yang cukup terjangkau bagi masyarakat. Maka disini pihak manajemen dituntut untuk bisa memberikan keyakinan kepada masyarakat atau konsumen setia Coffeenatics Medan, agar bisa kembali melakukan pembelian di cafe tersebut. Untuk dapat bertahan Coffeenatics Medan harus mengembangkan strategipemasarannyayaitudengan meningkatkan kualitas produk, harga, dan pelayanan.

Berdasarkan uraian di atas maka masalah yang dirumuskan dalam penelitian ini adalah apakah harga, kualitas produk dan kualitas pelayanan mempunyai pengaruh positif dan signifikan baik secara parsial maupun simultan terhadap kepuasan konsumen pada CoffeenaticsMedan?

\section{KAJIAN TEORITIS}

\section{Pengaruh Harga, Kualitas Produk dan Kualitas Pelayanan terhadap Kepuasan Konsumen.}

Harga merupakan salah satu variabel yang dikendalikan manajer pemasaran. Keputusan tingkat harga sangat penting karena mempengaruhi jumlah penjualan yang dapat dicapai perusahaan dan uang yang diperolehnya. Harga adalah segala sesuatu atau nilai yang ditetapkan bagi "sesuatu".Dalam arti yang paling sempit, harga adalah jumlah uang yang dibebankan atas suatu produk atau jasa. Lebih luas lagi, harga adalah jumlah dari seluruh nilai yang ditukar konsumen atas manfaat memiliki atau menggunakan produk atau jasa tersebut. (Kotler dan Amstrong, 2001). Dalam proses penetapan harga sebaiknya dilakukan sesuai dengan tujuan perusahaan dan pemasaran. Penetapan harga dilakukan perusahaan berdasarkan banyak pertimbangan.Menurut Stanton (2003), harga tidak 
lain hanyalah sebuah eksperimen untuk menguji denyut nadi pasar. Jika pelanggan menerima tawaran berarti harga tersebut sudah tepat. Jika mereka menolak biasanya harga akan cepat diganti atau bila perlu produk bisa ditarik dari peredarannya.Ada 4 (tempat) Indikator yang mencirikan hargayaitu,:

Kualitas produk merupakan kemampuan dari suatu produk dalam menjalankan fungsinya. Kualitas produk mempunyai hubungan yang sangat erat dengan kepuasan pelanggan karena kualitas produk dapat dinilai dari kemampuan produk tersebut untuk menciptakan kepuasanpelanggan.Kualitas dari suatu produk ditentukan oleh pelanggan melalui karakteristik yang ada pada suatu produk dan jasa, dimana puas dan tidaknya pelanggan dipengaruhi oleh nilai yang didapat dengan mengkonsumsi suatu produk. Semakin tinggi tingkat kualitas produk dalam memuaskan pelanggan, maka akan menyebabkan kepuasaan pelanggan yang tinggi pula (Kotler dan Amstrong,2008)

Kualitas produk menggambarkan sejauh mana kemampuan produk tersebut dalam memenuhi kebutuhan pelanggan. Definisi dari kualitas produk mencerminkan kemampuan produk untuk menjalankan tugasnya yang mencakup daya tahan, kehandalan atau kemajuan, kekuatan, kemudahan dalam pengemasandan reparasi produk dan ciri- ciri lainnya.

Kepuasan konsumen dapatdidefinisikan sebagai suatu keadaan dimana kebutuhan, keinginan, dan harapan konsumen dapat terpenuhi melalui produk yang dikonsumsi. Hal ini juga menemukan bahwa kepuasan keseluruhan relatif stabil sepanjang waktu. Penelitian juga menunjukkan bahwa loyalitas, kepuasan dan kualitas berhubungan erat. Alasan penelitian ini adalah berharga adalah karena juga menunjukkan kesetiaan yang dikaitkan dengan harga yang lebih menguntungkan konsumen. Secara umum dapat dikatakan bahwa kepuasan adalah perasaan senang atau kecewa seseorang yang berasal dari perbandingan antara kesannya terhadap kinerja (hasil) suatu produk dan harapannya. Pelanggan yang senang dan puas cenderung akan berperilaiku positif dan mereka akan membelikembali.

Faktor-faktor yang mempengaruhi kepuasan konsumen menurutRambatLupiyoadi (2001), dalam menentukan kepuasan konsumen, terdapat lima faktor utama yang harus diperhatikan oleh perusahaan, yaitu:

a) Kualitas Produk, Pelanggan akan merasa puas bila hasil evaluasi mereka menunjukan bahwa produk yang mereka gunakan berkualitas. 
b) Kualitas pelayanan Terutama untuk industri jasa pelanggan akan merasa puas bila mereka mendapatkan pelayanan yang baik atau yang sesuai dengan yang diharapkan.

c) Emosional, pelanggan akan merasa bangga dan mendapatkan keyakinan bahwa orang lain akan kagum terhadap dia bila menggunakan produk dengan merk tertentu yang cenderung mempunyai tingkat kepuasan yang lebihtinggi.

d) Harga, produk yang mempunyai kualitas yang sama tetapi menetapkan harga yang relatif murah akan memberikan nilai yang lebih tinggi kepada pelanggannya.

e) Biaya , pelanggan yang tidak perlu mengeluarkan biaya tambahan atau tidak perlu membuang waktu untuk mendapatkan suatu produk atau jasa cenderung puas terhadap produk atau jasaitu.

Fandy Tjiptono (2008)menyatakan bahwa metode yang paling banyak digunakan dalam pengukuran kepuasan konsumen adalah metode bertanya. Metode bertanya kepuasan konsumen dapat menggunakan tekhnik pengukuran sebagai berikut:

1) Pengukuran dapat dilakukan dengan memberikan pertanyaan secaralangsung.

2) Responden diberi pertanyaan mengenai seberapa besar mereka mengharapkan suatu atribut tertentu dan seberapa besar yang mereka rasakan (derived dissatisfaction).

3) Responden diminta untuk menuliskan masalah-masalah yang mereka hadapi berkaitan dengan penawaran dari perusahaan dan juga diminta untuk menuliskan perbaikan-perbaikan yang mereka sarankan (problemanalysis).

4) Responden dapat meminta untuk meranking beberapa elemen atribut dari penawaran berdasarkan derajat pentingnya setiap elemen dan seberapa baik kinerja perusahaan dalam masingmasing elemen (importance performance analysis).

\section{Manfaat KepuasanKonsumen}

Kepuasan konsumen dapat memberikan beberapa manfaat bagi perusahaan dan bagi konsumen itu sendiri. Manfaat yang dapat diperoleh dari kepuasan konsumen menurut Eriyanto Prastyo Nugroho dalam Fandy Tjiptono (2008) antara lain :

a. Hubungan antara perusahaan dan para pelanggannya menjadi harmonis

b. Memberikan dasar yang lebih baik untuk pembelian ulang 
c. Dapat mendorong terciptanya loyalitaskonsumen

d. Membentuk suatu rekomendasi dari mulut ke mulut (word-ofmouth) yang menguntungkan bagi perusahaan

e. Reputasi perusahaan menjadibaik

f. Laba yang diperoleh dapatmeningkat

Apa yang diharapkan dan diinginkan konsumen, merupakan faktor utama yang dapat dipertimbangkan oleh manajemen perusahaan dalam menyusun rencana kebijakan dalam pemasaran yang akan dilakukan perusahaan.

\section{Pengaruh Harga Terhadap KepuasanKonsumen}

Harga adalah sejumlah uang yang dibebankan atas suatu produk atau jasa, atau jumlah dari nilai yang ditukar pelanggan atas manfaatmanfaat karena memiliki atau menggunakan produk atau jasa tersebut. (Kotler dan Amstrong : 2014 ). Dalam membeli suatu produk pelanggan tidak hanya mempertimbangkan kualitasnya saja, tetapi juga memikirkan kelayakan harganya. Harga merupakan salah satu penentu pemilihan produk yang nantinya akan berpengaruh terhadap kepuasan. Harga seringkali dikaitkan dengan kualitas, pelanggan cenderung untuk menggunakan harga sebagai indikator kualitas atau kepuasan potensial dari suatu produk.

Bila suatu produk mengharuskan pelanggan mengeluarkan biaya yang lebih besar dibandingkan dengan manfaat yang diterima, maka yang terjadi adalah produk tersebut memiliki nilai negatif. Sebaliknya, apabila pelanggan mengganggap bahwa manfaat yang diterima lebih besar, maka yang terjadi adalah produk tersebut memiliki nilai yang positif. Para pelanggan tertarik untuk mendapatkan harga yang pantas. Harga yang pantas berarti nilai yang di persepsikan pantas pada saat transaksi dilakukan. Pelanggan beranggapan bahwa suatu produk dengan harga yang mahal berarti mempunyai kualitas yang baik.

Harga merupakan variabel yang dapat dikendalikan dan menentukan diterima atau tidaknya suatu produk oleh pelanggan. Harga semata-mata tergantung pada kebijakan perusahaan, tetapi tentu saja dengan mempertimbangkan beberapa hal. Murah atau mahalnya harga suatu produk sangat relatif sifatnya. Untuk mengatakannya perlu terlebih dahulu dibandingkan dengan harga produk serupa yang di produksi atau dijual perusahaan lain. Perusahaan perlu memonitor harga yang ditetapkan oleh para pesaing agar harga yang ditentukan oleh perusahaan tidak terlalu tinggi atau sebaliknya, sehingga harga yang ditawarkan apabila sesuai 
dengan apa yang diharapkan pelanggan akan dapat menimbulkan kepuasan pelanggan. Hasil penelitian Arlina Nurbaity dan Martin (2009) menyatakan bahwa harga berpengaruh positip terhadap kepuasan pelanggan. Harga akan mempengaruhi kepuasan pelanggan apabila harga suatu produk sesuai dengan kualitas, terjangkau, dan sesuai dengan manfaat yang diterima menimbulkan kepuasan padapelanggan.

Banyak hal yang berkaitan dengan harga yang melatarbelakangi mengapa pelanggan memilih suatu produk untuk dimilikinya. Pelanggan memilih suatu produk tersebut karena benar-benar ingin merasakan nilai dan manfaat dari produk tersebut, karena melihat kesempatan memiliki produk tersebut dengan harga yang lebih murah dari biasanya sehingga lebih ekonomis, kerena ada kesempatan untuk mendapatkan hadiah dari pembelian produk tersebut, atau karena ingin dianggap pelanggan lain bahwa tahu banyak tentang produk tersebut dan ingin dianggap loyal.

Harga dilihat dari sudut pandang pelanggan, seringkali digunakan sebagai Indikator nilai bilamana harga tersebut dihubungkan dengan manfaat yamg dirasakan atas suatu barang atau jasa. Kertajaya (2002)mengungkapkan bahwa indikator penilaian harga dapat dilihat dari kesesuaian antara suatu pengorbanan dari pelanggan terhadap nilai yang diterimanya setelah melakukan pembelian, dan dari situlah pelanggan akan mempersepsi dari produk atau jasa tersebut. Jika harga yang ditetapkan oleh sebuah perusahaan tidaksesuaidengan manfaat produk maka hal itu dapat menurunkan tingkat kepuasan pelanggan, dan sebaliknya jika harga yang ditetapkan oleh sebuah perusahaan sesuai dengan manfaat yang diterima maka akan meningkatkan kepuasan pelanggan.

Dengan demikian dapat disimpulkan bahwa pada tingkat harga tertentu, jika manfaat yang dirasakan meningkat, maka nilainya akan meningkat pula. Apabila nilai yang dirasakan pelanggan semakin tinggi, maka akan menciptakan kepuasan pelanggan yang maksimal (Tjiptono,2008).

\section{Pengaruh Kualitas Produk Terhadap KepuasanKonsumen}

Produk didefinisikan sebagai sesuatu yang dapat ditawarkan kedalam pasar untuk diperhatikan, dimiliki, dipakai, atau dikonsumsi sehingga dapat memuaskan kebutuhan atau keinginan. Produk yang berkualitas adalah produk yang mampu memberi manfaat yang lebih dari yang diharapkan. Apabila diutarakan lebih rinci kualitas memiliki dua prspektif yaitu perspektif produsen \& pelanggan, dimana bila kedua hal itu digabungkan maka yang akan dapat tercapai kesesuaian yang dapat 
digunakanpelanggan.

Dalam dunia usaha, istilah kualitas sangat penting bagi perusahaan, karena; reputasi perusahaan, penurunan biaya, peningkatan pangsa pasar, dan penampilan produk.suatu produk dikatakan berkualitas bila mempunyai nilai subyektifitas yang tinggi antara pelanggan yang satu dengan pelanggan yang lain. Hadi (2002) mengatakan bahwa kepuasan pelanggan sangat tergantung pada bagaimana tin kualitas produk (diukur dari persepsi pelanggan atas tingkat kerusakan produk) mempengaruhi tingkat kepuasan pelanggan. Kepuasan pelanggan mengindikasikan adanya kesetiaan pelanggan terhadap produk, serta dapat mengurangi elastisitas harga, mencegah pelanggan direbut pesaing, biaya transaksi mendatang lebih murah, mengurangi biaya kegagalan, dan dapat meningkatakan reputasi perusahaan.

Konsumen akan memiliki harapan mengenai bagaimana produk tersebut seharusnya berfungsi ( performance expectation). Harapan tersebut adalah standar kualitas yang akan dibandingkan dengan fungsi atau kualitas produk yang sesungguhnya dirasakan konsumen. Fungsi produk yang sesungguhnya dirasakan konsumen, (actual performance) sebenarnya merupakan persepsi konsumen terhadap kualitas produk tersebut.

Di dalam suatu proses keputusan, konsumen tidak akan berhenti pada proses konsumsi saja. Konsumen akan melakukan proses evakuasi terhadap konsumsi yang telah dilakukanya. Inilah yang disebut evaluasi alternatif pasca pembelian atau pasca konsumsi. Proses ini juga dapat disebut proses evaluasi alternatif tahap kedua. Hasil dari proses evaluasi pasca konsumsi adalah kepuasan atau ketidakpuasan terhadap konsumsi produk atau merek yang telah dilakukanya. Setelah mengonsumsi suatu produk atau jasa, konsumen akan memiliki perasaan puas atau tidak puas terhadap produk atau jasa yang dikonsumsinya. Kepuasan akan mendorong konsumen untuk membeli dan mengonsumsi ulang produk tersebut. Sebaliknya, perasaan yang tidak puas akan menyebabkan konsumen kecewa dan menghentikan pembelian kembali dan konsumsi produktersebut.

\section{Pengaruh Kualitas Pelayanan Terhadap KepuasanKonsumen}

Kualitas layanan adalah suatu bentuk penilaian pelanggan terhadap tingkat layanan yang diterima dengan tingkat yang diharapkan (Rahmat Lupiyoadi, 2001). Pada umumnya harapan palanggan merupakan perkiraan atau keyakinan pelanggan tentang apa yang akan diterimanya 
apabila ia membeli atau mengkonsumsi suatu produk baik barang maupun jasa, sedangkan kinerja atau hasil yang dirasakan merupakan persepsi pelanggan terhadap apa yang ia terima setelah mengkonsumsi produk yang ia beli.

Kualitas pelayanan merupakan evaluasi pelanggan tentang kesempurnaan kinerja layanan. kualitas pelayanan mempunyai pengaruh positif terhadap kepuasan pelanggan. Jadi dengan peningkatan kualitas layanan yang diberikan kepada pelanggan maka kepuasan pelanggan akan tercipta. Berdasarkan hasil penelitian yang dilakukan oleh Kartika Sukmawati (2011) mengemukakan bahwa terdapat pengaruh positif antara kualitas pelayanan terhadap kepuasan pelanggan. Hal ini berarti bahwa kualitas pelayanan pelanggan jasa Transportasi Kereta ApiEksekutif memiliki pengaruh yang signifikan terhadap kepuasan pelanggannya.

Kualitas pelayanan yang berdimensi empathy, responsiveness, assurance" dan tangibles dapat memunculkan kepuasan bagi pelanggan. Dalam penelitian Saidini dan Arifin (2012) menjelaskan bahwa kualitas pelayanan dapat meningkatkan kepuasan pelanggan dengan responsiveness sebagai dimensi yang paling dominan.

Pada umumnya harapan palanggan merupakan perkiraan atau keyakinan pelanggan tentang apa yang akan diterimanya apabila ia membeli atau mengkonsumsi suatu produk baik barang maupun jasa, sedangkan kinerja atau hasil yang dirasakan merupakan persepsi pelanggan terhadap apa yang ia terima setelah mengkonsumsi produk yang ia beli.

Kualitas pelayanan merupakan evaluasi pelanggan tentang kesempurnaan kinerja layanan. kualitas pelayanan mempunyai pengaruh positif terhadap kepuasan pelanggan.Jadi dengan peningkatan kualitas layanan yang diberikan kepada pelanggan maka kepuasan pelanggan akan tercipta.

Berdasarkan hasil penelitian yang dilakukan olehKartika Sukmawati (2011) mengemukakan bahwa terdapat pengaruh positif antara kualitas pelayanan terhadap kepuasan Pelanggan. Hal ini berarti bahwa kualitas pelayanan pelanggan jasa Transportasi Kereta Api Eksekutif memiliki pengaruh yang signifikan terhadap kepuasan pelanggannya

\section{Pengaruh harga kualitas produk dan kualitas pelayanan terhadap kepuasankonsumen}

Menurut teori tingkah laku konsumen dalam pendekatan nilai guna kordinal dan nilai guna ordinal, yaitu: 
1) Semakin besar kepuasan yang didapat maka makin mahal harganya. Jika konsumen memperoleh tingkat kepuasan yang besar maka dia akan mau membayar mahal, sebaliknya jika kepuasan yang dirasakan konsumen rendah maka dia hanya akan mau membayar dengan harga yang murah.

2) Semakin banyak produk yang dikonsumsi maka makin besar kepuasan yang didapatkan.

3) Konsumen lebih menyukai yang lebih banyak dari pada yang lebih sedikit, artinya semakin banyak barang yang dikonsumsi menunjukkan semakin tingginya tingkat kepuasan yangdimilikinya.

4) Kualitas pelayanan yang tinggi dan baik menghasilkan kepuasan konsumen yang tinggi pula. Sebaliknya ketidakpuasan atas kualitas layanan dapat dijadikan alasan konsumen untukberpindah.

\section{METODE PENELITIAN}

\section{Populasi dan Sampel}

Populasi dalam penelitian ini adalah konsumen yang sedang berkunjung ke Coffeenatics Medan. Pengambilan sampel dilakukan dengan teknik accidental sampling, yaitu peneliti memilih siapa saja anggota populasi yang secara kebetulan bertemu dengan peneliti dianggap dapat memberikan informasi yang diperlukan. Kriteria yang digunakan peneliti adalah responden yang telah melakukan pembelian di Coffeenatics Medan minimal 1 kali. Kriteria tersebut digunakan mengingat besarnya jumlah populasi.

\section{Operasionalisasi Variabel}

\begin{tabular}{|c|c|c|c|}
\hline Variabel & \multicolumn{1}{|c|}{ Definisi Variabel } & \multicolumn{1}{c|}{ Indikator } & $\begin{array}{c}\text { Skala } \\
\text { Pengukuran }\end{array}$ \\
\hline Harga (X1) & $\begin{array}{l}\text { Persepsi dari sebuah uang yang } \\
\text { dibutuhkan untuk mendapatkan } \\
\text { sejumlah kombinasi dari } \\
\text { barang beserta pelayanannya }\end{array}$ & $\begin{array}{l}\text { 1. Harga sesuai dengan } \\
\text { manfaatnya . } \\
\text { 2. Kewajaranharga } \\
\text { 3. Perbandinganharga }\end{array}$ & \\
\hline
\end{tabular}




\begin{tabular}{|c|c|c|c|}
\hline $\begin{array}{l}\text { Kualitas Produk } \\
\qquad \text { ( X2) }\end{array}$ & $\begin{array}{l}\text { Persepsi dari sebuah uang yang } \\
\text { dibutuhkan untuk mendapatkan } \\
\text { sejumlah kombinasi dari } \\
\text { barang beserta pelayanannya }\end{array}$ & $\begin{array}{l}\text { 1. Rasa minuman, } \\
\text { 2. Menu yangvariatif } \\
\text { 3. Penyajian bentuk } \\
\text { hidangan } \\
\text { 4. Kebersihan dan } \\
\text { kesegaran setiap } \\
\text { produk }\end{array}$ & Likert \\
\hline $\begin{array}{l}\text { Kualitas } \\
\text { pelayanan } \\
\text { (X3) }\end{array}$ & $\begin{array}{l}\text { Pelayanan yang diberikan } \\
\text { kepada pelanggan sesuai } \\
\text { standar pelayanan Coffeenatics } \\
\text { yang mencakup keandalan, } \\
\text { tanggapan dan } \\
\text { perhatian }\end{array}$ & $\begin{array}{l}\text { 1. Keandalan } \\
\text { (reliability) } \\
\text { 2. Daya tangkap } \\
\text { (responsiveness). } \\
\text { 3. Jaminan(assurance) }\end{array}$ & Likert \\
\hline $\begin{array}{l}\text { Kepuasan } \\
\text { Konsumen } \\
\text { (Y) }\end{array}$ & $\begin{array}{l}\text { Kepuasan pelanggan } \\
\text { merupakan tingkat perasaan } \\
\text { seseorang setelah } \\
\text { membandingkan antara kinerja } \\
\text { produk/jasa yang ia rasakan } \\
\text { dengan harapannya. }\end{array}$ & $\begin{array}{l}\text { 1. Kinerja } \\
\quad \text { (performance) } \\
\text { 2. Harapan (expectation) } \\
\text { 3. Rekomendasi }\end{array}$ & Likert \\
\hline
\end{tabular}

Sumber:Olahan Penulis

\section{Teknik AnalisisData}

Teknik analisis data yang digunakan peneliti dalam penelitian ini adalah dengan menggunakan:

\section{Uji Validitas}

Suatu instrument dikatakan valid apabila dapat mengungkapkan data dari variabel untuk mengukur tingkat validitas soal yang diteliti secara tepat. Kriteria dalam menentukan validitas suatu kuesioner adalah sebagai berikut:

Jika $r \geq 0,30$ maka pertanyaan tersebut valid.

Jika $r<0,30$ maka pertanyaan tersebut tidak valid.

\section{Uji Reliabilitas}

Reliabilitas adalah alat yang digunakan untuk mengukur suatu kuesioner yang merupakan indikator dari suatu variabel. Kriteria dalam menentukan reliabilitas suatu kuesioner adalah sebagai berikut:

$\alpha \geq 0,50$ artinya instrumen reliabel.

$\alpha<0,50$ artinya instrumen tidak reliabel.

Teknik analisis yang digunakan dalam penelitian ini adalah analisis regresi berganda, dengan persamaan sebagai berikut:

$\mathrm{Y}=\mathbf{a}+\mathrm{b} 1 \mathrm{X} 1+\mathrm{b} 2 \mathrm{X} 2+\mathrm{b3X3}+\mathrm{ei}$ 
Dimana :

Y : Kepuasan Konsumen

$\mathrm{X} 1$ : Variabel harga

$\mathrm{X} 2$ : Variabel kualitas produk

X3 : Variabel kualitaspelayanan

b1 : Koefisien regresi variable harga

b2 : Koefisien regresi variabel kualitas produk b3 : Koefisien regresi

variabel kualitas pelayanan

a :Konstanta

ei $=$ Tingkat kesalahan estimasi

Pengujian model regresi linear berganda ini digunakan untuk mengetahui pengaruh dari variabel (harga, kualitas produk, kualitas pelayanan) terhadap variabel terikat (kepuasan konsumen).

\section{PengujianHipotesis}

\section{Uji Simultan (UjiF)}

Uji $\mathrm{F}$ dilakukan untuk melihat apakah semua variabel bebas yang dimasukkan dalam model mempunyai pengaruh secara bersama-sama terhadap variabel terikat.

Langkah-langka hnya sebagai berikut:

1. $\mathrm{H} 0: \mathrm{B}_{\mathrm{i}}=0$, artinya harga, kualitas produk, dan kualitas pelayanan tidak berpengaruh signifikan terhadap kepuasan konsumen di Coffenatics Medan.

$\mathrm{Ha}: \mathrm{B}_{\mathrm{i}} \neq 0$, artinya harga, kualits produk, dan kualitas pelayanan berpengaruh signifikan

2. $(\alpha)=5 \%$

terhadap kepuasan konsumen di Coffeenatics Medan.

3. Uji Statistik

4. Kriteria keputusan:

Jika $p$ value $\leq \alpha(0.05)$, maka Ho ditolak

Jika $\mathrm{p}$ value $>\alpha(0.05)$, maka Ho tidak ditolak

5. Kesimpulan

\section{Uji Parsial (ujit)}

Uji t digunakan untuk menunjukkan apakah harga, kualitas produk, dn kualitas pelayanan secara parsial berpengaruh positif dan signifikan terhadap kepuasan konsumen.

Langkah-langkahnya sebagai berikut: 
1. $\mathrm{H} 0: \mathrm{Bi} \leq 0$, artinya tidak terdapat pengaruh positif dan signifikan secara parsial antara

harga, kualitas produk dan kualitas pelayanan terhadap kepuasan konsumen pada

CoffeenaticsMedan.

$\mathrm{H} 1$ : $\mathrm{Bi}>0$, artinya terdapat pengaruh positif dan signifikan secara parsial antara harga

kualitas produk, dan kualitas pelayanan terhadap kepuasan konsumen Coffeenatics

Medan.

2. Tingkat kepercayaan $95 \%$

3. Uji Statistik

$\mathrm{t}=\mathrm{b} / \mathrm{Sb}$

Keterangan:

$t$ : thitung

b : Koefisienregresi

$\mathrm{Sb}:$ Standar error estimate

4. Kriteria keputusan:

Jika $\mathrm{p}$ value $\leq \alpha(0.05)$, maka Ho ditolak

Jika $\mathrm{p}$ value $>\alpha(0.05)$, maka Ho tidak ditolak

5. Kesimpulan : Dapat disimpulkan apakah hipotesis diterima atauditolak.

\section{Kofisien Determinasi $\left(\mathbf{R}^{2}\right)$}

Kofisien determinasi $\left(\mathbf{R}^{\mathbf{2}}\right)$ digunakan untuk mengukur seberapa besar kemampuan variabel bebas menjelaskan variasi variabel terikat. Jika koefisien determinasi $\left(\mathbf{R}^{2}\right)$ semakin besar (mendekati satu) menunjukkan semakin besar kemampuan variabel bebas menjelaskan variasi variabel terikat dimana $0 \square \mathbf{R}^{\mathbf{2}} \square$ 1. Sebaliknya, jika $\mathbf{R}^{\mathbf{2}}$ semakin kecil (mendekati nol) maka dapat dikatakan bahwa semakin kecil kemampuan variabel bebas untuk menjelaskan variasi variabel terikat. Hal ini berarti model yang digunakan tidak kuat untuk menerangkan pengaruh variabel bebas yang diteliti terhadap variabel terikat.

\section{HASIL PENELITIAN DAN PEMBAHASAN}

\section{Harga, Kualitas Produk, dan Kualitas Pelayanan PadaCoffeenatics}

Coffeenatics mencoba menawarkan harga yang cukup bersaing dengan café lain yang sejenis, kemudian untuk semakin memuaskan 
konsumen pada hari-haritertentu seperti hari Ibu, hari Kemerdekaan, atau hari Natal dan Tahun Barudan lain-lain, Coffeenatics memberikan potongan harga pada konsumen yang beruntung, ditambah dengan pemberikan hadiah seperti baju Coffeenatics, pin, dan gelang tangan.

Tabel 3 Daftar Harga Kopi \& Beer di Coffeenatics Medan

\begin{tabular}{|l|c|}
\hline \multicolumn{1}{|c|}{ Menu } & Harga \\
\hline Espresso & 21.000 \\
\hline Caffe Americano & 26.000 \\
\hline Caffe Latte & 34.000 \\
\hline Caffe Latte with Flavour & 39.000 \\
\hline Caffe Mocha & 34.000 \\
\hline Cappocino & 34.000 \\
\hline Flat White & 34.000 \\
\hline Piccolo Latte & 30.000 \\
\hline Iced Caffe Americano & 26.000 \\
\hline Iced Caffe Latte & 34.000 \\
\hline Iced Caffe Latte with Flavour & 39.000 \\
\hline Iced Caffe Mocha & 34.000 \\
\hline Iced Cappoccino & 34.000 \\
\hline Coffeenatics Iced Latte & 34.000 \\
\hline Salted Caramel Latte & 39.000 \\
\hline Black and White & 34.000 \\
\hline Espresso Bomb & 34.000 \\
\hline Salted Caramel Affogato & 39.000 \\
\hline Caramel Frappe & 39.000 \\
\hline Hazelnut Frappe & 39.000 \\
\hline Martini Coffee Cocktail & 74.000 \\
\hline Classick Russians & 56.000 \\
\hline Stout Coffee Cocktail & 43.000 \\
\hline Beer Bucket & 174.000 \\
\hline Cinder Fiesta & 217.000 \\
\hline
\end{tabular}

Sumber : Coffeenatics Medan 
Tabel 4 Daftar Harga Makanan di Coffeenatics Medan

\begin{tabular}{|l|c|}
\hline \multicolumn{1}{|c|}{ Menu } & Harga \\
\hline Coffeenatics Benedict & 69.000 \\
\hline Scrambel Egg Burrito & 65.000 \\
\hline Cheese and Mushroom Omelette & 60.000 \\
\hline Egg and Soldiers & 21.000 \\
\hline Scrambled Eggs on Toast & 30.000 \\
\hline Green Salad With Sasame Ginger & 34.000 \\
\hline Lettuce Salad With Chipotle Dressing & 34.000 \\
\hline Asparagus Cream Soup & 34.000 \\
\hline Prawn Bisque & 34.000 \\
\hline Spaghetti Aglio E Ollio & 39.000 \\
\hline Spaghetti Alla Fra Diavolo & 82.000 \\
\hline Penna Alla Carbonara & 69.000 \\
\hline Coffeenatics Seafood Fried Noodles & 65.000 \\
\hline Indonesian Special Fried Rice & 52.000 \\
\hline Indonesian Chicken Soup With Rice & 47.000 \\
\hline Roasted Baby Spring Chicken & 82.000 \\
\hline Bowl of Fries/ Onion Rings & 30.000 \\
\hline Crunchy Chicken Fingers with Souce & 43.000 \\
\hline Potato Wedges with Chili Mesr Souce & 43.000 \\
\hline Tortilla Chips With Spinach Dip & 39.000 \\
\hline Sweet Bite & 30.000 \\
\hline Coffeenatics Creame Brulee & 30.000 \\
\hline Banana Bread with Home Marmalade & 17.000 \\
\hline Salted Caramel Brownies & 26.000 \\
\hline Whole Banana Bread & 156.000 \\
\hline Whole Salted Caramel Brownies & 174.000 \\
\hline
\end{tabular}

Sumber : Coffeenatics Medan

Kualitas produk merupakan gambaran sejauh mana kemampuan produk tersebut dalam memenuhi kebutuhan pelanggan. Dalam hal kualitas dari produk Coffeenatics sangat berusaha untuk menjamin kualitas dari produk yang mereka jual, contohnya pada daerah-daerah tertentu kopi pemilik café dan para barista memetik langsung kopi yang akan di olah ke kebunnya, ikut dalam proses penjemuran, dan untuk proses penggilingan akan di bawa langsung ke cafe. Sehingga konsumen semakin percaya akan 
kualitas dari produk yang mereka minum. Untuk makanan dan cake Coffeenatics langsung memilh chef professional yaitu adik dari pemilik Coffeenatics untuk menjamin kualitas dari masakan yang dihidangkan padakonsumen.

Kualitas pelayanan adalah suatu pernyataan tentang sikap, hubungan yang dihasilkan dari perbandingan antara harapan dengan kinerja. Harapan dari konsumen dalam hal pelayanan setiap saat selalu berubah sehingga Coffeenatics selalu melakukan penyesuaian dengan harapan pelanggan. Konsumen akan menilai pelayanan yang diberikan oleh suatu perusahaan dengan membandingkan dari perusahaan satu dengan perusahaan lain yang sejenis, juga dengan membandingkan pelayanan yang diterima dengan pelayanan yang diharapkannya. Pada prinsipnya kualitas pelayanan berfokus pada upaya pemenuhan kebutuhan dan keinginan konsumen sesuai dengan yang di harapkankosumen.

Coffeenatics mengupayakan pelayanan yang sangat baik bagi konsumen, para pelayan di tuntut untuk selalu rapi, sopan dan ramah kepada konsumen, setiap saran dan kritk dari konsumen merupakan evaluasi yang sangat dihargai oleh pemilik café demi kelangsungan dariCoffeenatics.

\section{Uji Hipotesis}

Output SPSS pada penelitian ini dapat dilihat pada tabel ANOVA berikut:

Tabel 5 ANOVAa

\begin{tabular}{|rl|r|r|l|l|l|}
\hline \multicolumn{2}{|l|}{ Model } & $\begin{array}{r}\text { Sum of } \\
\text { Squares }\end{array}$ & Df & $\begin{array}{l}\text { Mean } \\
\text { Square }\end{array}$ & F & Sig. \\
\hline \multirow{2}{*}{1} & Regression & 229,972 & 3 & 76,657 & 26,985 &, $000^{\mathrm{b}}$ \\
& Residual & 258,512 & 91 & 2,841 & & \\
& Total & 488,484 & 94 & & & \\
\hline
\end{tabular}

a. Dependent Variable:TY

b. Predictors: (Constant), TX3, TX1,TX2

Sumber : Data diolah

Dari tabel 5 dapat dilihat bahwa terdapat pengaruh yang signifikan antara variabel bebas yaitu harga, kualitas produk dan kualitas pelayanan terhadap variabel kepuasan konsumen. Hal tersebut ditunjukkan dari nilai $\mathrm{P}$ value $(0,000)<\alpha(0,05)$ sehingga dapat disimpulkan bahwa H0 ditolak, artinya variabel harga, kualitas produk, kualitas pelayanan berpengaruh signifikan terhadap kupuasan pelanggan pada Coffeenatics Medan. 
Tabel 6 Coefficients ${ }^{\mathrm{a}}$

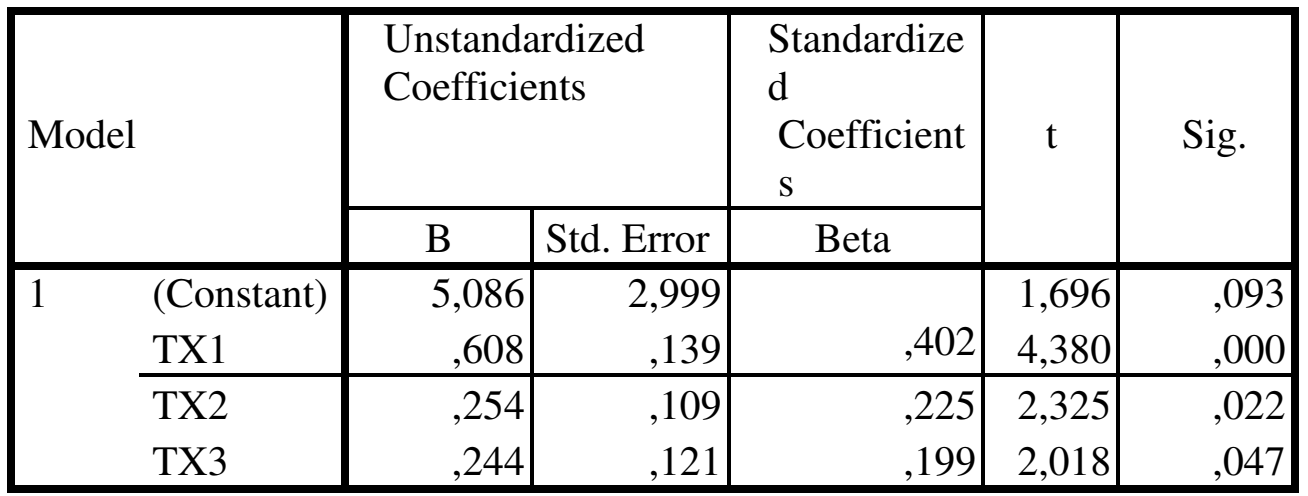

a. Dependent Variable: Y

Sumber : Data diolah

Dari tabel 6 dapat dilihat bahwa harga berpengaruh positif dan signifikan terhadap kepuasan konsumen pada Coffeenatics Medan. Hal ini dapat dilihat dari nilai $\mathrm{P}$ value $(0,000)<\alpha(0.05)$. Untuk variabel kualitas produk berpengaruh positif dan signifikan terhadap kepuasan konsumen dilihat dari nilai $\mathrm{P}$ value $(0,022)<\alpha(0.05)$. Untuk variabel kualitas pelayanan berpengaruh positif dan signifikan terhadap kepuasan konsumen dilihat dari nilai $\mathrm{P}$ value $(0,047)<\alpha(0.05)$.

Dari tabel diatas dapat dirumuskan persamaan regresi berganda sebagai berikut: $\quad Y=\mathbf{5 , 0 8 6 + 0 , 6 0 8 X 1 + 0 , 2 5 4 X 2 + 0 , 2 4 4 X 3 + ~ e i . ~ D a r i ~}$ persamaan tersebut dapat dijelaskan beberapa hal. Pertama, ketiga variabel bebas ( harga, kualitas produk, kualitas pelayanan) mempunyai hubungan yang positif dengan kepuasan konsumen pada Coffeenatics Medan. Hal ini dapat dil;ihat dari koefisien regresi yang bertanda positif. Kedua, nilai konstanta sebesar 5,086 artinya jika nilai harga kualitas produk, kualitas pelayanan nol maka nilai kepuasan konsumen sebesar5,086.Ketiga, koefisien regresi harga $=0,608$ artinya apabila harga naik 1 satuan maka kepuasan konsumen akan naik sebesar 0,608 satuan dan apabila harga turun 1 satuan maka kepuasan konsumen akan turun $.0,608$ satuan.Keempat, koefisien regresi kualitas produk $=0,254$ artinya apabila kualits produk naik 1 satuan maka kepuasan konsumen akan naik sebesar 0,254 satuan satuan dan apabila kualitas produk turun 1 satuan maka kepuasan konsumen akan turun 0,254satuan.Kelima, koefisien regresi kualitas pelayanan $=0,244$ artinya apabila kualitas pelayanan naik 1 satuan maka kepuasan konsumen akan naik sebesar 0,244 satuan dan apabila kualitas pelayanan turun 1 satuan maka kepuasan konsumen akan turun 0,244 satuan. 
Tabel 7 Model Summary

\begin{tabular}{|l|c|r|r|c|}
\hline Model & $\mathrm{R}$ & $\mathrm{R}$ Square & $\begin{array}{c}\text { Adjusted R } \\
\text { Square }\end{array}$ & $\begin{array}{c}\text { Std. Error of the } \\
\text { Estimate }\end{array}$ \\
\hline 1 &, $686^{\mathrm{a}}$ &, 471 &, 453 & 1,685 \\
\hline
\end{tabular}

a. Predictors: (Constant), X3, X1, X2

Sumber : Data diolah

Berdasarkan tabel 7 diatas terlihat bahwa:Nilai $\mathrm{R}$ sebesar 0,686 atau $68,6 \%$ berarti hubungan antara variabel harga, kualitas produk, kualitas pelayanan terhadap kepuasan konsumensedang.Koefisien determinasi (R Square) adalah 0,471 atau $47,1 \%$ berarti variabel harga, kualitas produk, kualitas pelayanan mampu menjelaskan variasi kepuasan konsumen sebesar $47,1 \%$ dan sisanya sebesar 0,529 atau $52,9 \%$ dapat dijelaskan oleh faktor lain yang tidak terasuk dalam penelitian ini seperti lokasi, promosidll.

\section{Pembahasan}

Berdasarkan pengujian hipotesis, harga berpengaruh positif dan signifikan terhadap kepuasan konsumen Coffeenatics Medan, karena nilai $\mathrm{P}$ value $(0,000)<\alpha(0,05)$. Berarti harga yang ditawarkan Oleh Coffeenatics cukup bersaing dengan cafe lain yang sejenis. Penelitian ini sesuai dengan penelitian yang dilakukan Rina Sukmawati (2017) melakukan penelitian n judul "Pengaruh Kualitas Produk,Harga, dan Pelayanan Terhadap Kepuasan Konsumen pada Garden Cafe Koperasi Mahasiswa Universitas Negeri Yogyakarta”. Hasil penelitian tersebut menunjukkan bahwa kualitas produk, harga, dan kualitas pelayanan memberikan pengaruh yang positif dan signifikan terhadap Kepuasan Konsumen Garden Cafe Koperasi Mahasiswa Universitas Negeri Yogyakarta.

Variabel kualitas produkberpengaruh positif dan signifikan terhadap kepuasan konsumenCoffeenatics Medan, karena nilai $\mathrm{P}$ value $(0,022)<\alpha(, 0,05)$. Hasil penelitian ini sesuai dengan penelitian yang dilakukan Annisa Fiazisyah (2018) degan judul "Pengaruh Kualitas 
Produk, Harga dan Kualitas Pelayanan Terhadap Kepuasan Konsumen Restoran Cepat Saji KFC Basuki Rahmat Surabaya”. Hasil penelitian tersebut menunjukkan bahwa variabel kualitas produk, harga, dan kualitas pelayanan memberikan pengaruh yang positif dan signifikan terhadap kepuasan konsumen restoran cepat saji KFC Basuki RahmatSurabaya.

Variabel kualitas pelayanan berpengaruh positif dan signifikan terhadap kepuasan konsumenCoffeenatics Medan, karena nilai $\mathrm{P}$ value $(0,047)<\alpha(, 0,05)$. Hasil penelitian ini sesuai dengan penelitian yang dilakukan Kartika Sukmawati (2011) degan judul "Pengaruh Kualitas Layanan, Harga dan kepuasan pelanggan Terhadap loyalitas pelanggan Jasa Transportasi Kereta Api Eksekutif'. Hasil penelitian tersebut menunjukkan bahwa variabel kualitas layanan, harga, dan kepuasan pelanggan memberikan pengaruh yang positif dan signifikan terhadap loyalitas pelanggan jasa transportasi Kereta Api Eksekutif.

Secara simultan, terdapat pengaruh signifikan antara variabel harga, kualitas produk, dan kualitas pelayanan terhadap kepuasan konsumenpada Coffeenatics Medan. Pengaruh tersebut ditunjukkan oleh nilai $\mathrm{P}$ value $(0,000)<\alpha(0,05)$. Maka apabila indikator ketiga variabel bebas lebih diperhatikan yaitu harga, kualitas produk dan kualitas harga, maka kepuasan konsumen Coffeenatics Medan semakin meningkat dan hal ini akan semakin meningkatkan daya saing dari Coffeenatica Medan dan saingannya. Harga perlu lebih disesuaikan dengan daya beli masyarakat, kualitas produk menyangkut cita rasa, variasi, keunikan, dan kebersihan produk serta kualitas pelayanan seperti waiter/waters yang ramah, cepat tanggap, cekatan rapi dan bersih perlu tetap mendapat perhatian dari pimpinan bahkan kalau memungkinkan semakin ditingkatkan.

\section{KESIMPULAN DAN SARAN}

Berdasarkan hasil pembahasan, dapat ditarik beberapa kesimpulan:

1. Persamaan regresi linear berganda yang diperoleh sebagai berikut:

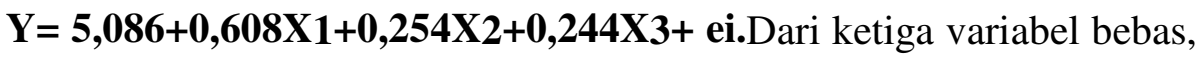


harga mempunyai pengaruh yang lebih besar terhadap kepuasan konsumen karena memiliki koefisien regresi palingbesar yaitu 0,608.

2. Dari hasil uji $\mathrm{F}$, diperoleh bahwa harga $\left(\mathrm{X}_{1}\right)$, kualitas produk $\left(\mathrm{X}_{2}\right)$, dan kualitas pelayanan (X3) berpengaruh signifikan terhadap kepuasan konsumen (Y) pada Coffeenatics Medan. Hal ini dapat dilihat dari nilai p value $(0,000)<\alpha(0,05)$.

3. Harga $\left(\mathrm{X}_{1}\right)$, kualitas produk $\left(\mathrm{X}_{2}\right)$, dan kualitas pelayanan secara parsial berpengaruhpositif dan signifikan secara parsial terhadap kupuasan konsumen pada CoffeenaticsMedan.Halinidapatdilihatdaritingkat signifikansinya variabel harga sebesar $0,000<\alpha(0,05)$. tingkat signifikansi variable kualitas produk sebesar $0,022<\alpha(0,05)$, nilai signifikansi variabel kualitas pelayanan sebesar $0,000<\alpha(0,05)$.

4. Koefisien determinasi ( $\mathrm{R}$ Square) adalah 0,471 atau $47,1 \%$ berarti variasi kepuasan konsumen dapat dijelaskan oleh variasi harga, kualitas produk, kualitas pelayanan sebesar $47,1 \%$ dan sisanya sebesar 0,589 atau $56,9 \%$ dapat dijelaskan oleh faktor lain diluar variabel seperti faktor lokasi, promosi dll.

Berdasarkan kesimpulan diatas maka Coffeenatics Medan penting mempertahankan harga dan kualitas produk serta meningkatkan kualitas pelayanan yang baik yaitu Excelent service untuk semakin memberikan kepuasan kepada konsumen.

\section{DAFTAR PUSTAKA}

Fiazisyah Annisa. 2018. Pengaruh Kualitas Produk, Harga dan Kualitas Pelayanan Terhadap Kepuasan Konsumen Restoran Cepat Saji KFC Basuki Rahmat Surabaya.

Hadi. 2002. Manajemen Kualitas Produk. Edisi10. Jilid 1. Jakarta.

Kertajaya, Hermawan. 2002. Markplus on stratehy: 12 Tahun Perjalanan Markplus \& Co MembangunStrategi Pemasaran. Jakarta: Gramedia Pustaka Utama

Kotler, Philip, dan Gary Amstrong, 2014. Prinsip-Prinsip Pemasaran edisi ke 12, Jakarta: Erlangga. 
Lupiyadi, Rahmat. 2001. Manajemen Pemasaran Jasa, Teori dan Praktek. Edisi Pertama. Jakarta: Salemba Empat.

Sukmawati, Kartika. 2011. Pengaruh Kualitas Layanan, Harga, dan Kepuasan Pelanggan Terhadap Loyalitas Pelanggan Jasa Transportasi Kereta Api Eksekutif.

Sukmawati, Rina. 2017. Pengaruh Kualitas Produk, Harga, dan Pelayanan Terhadap Kepuasan Konsumen Garden Cafe Koperasi Mahasiswa Universitas Negeri Yogyakarta.

Staton, William J. 2003. Prinsip pemasaran. Alih bahasa oleh Sadu Sundaru.Jilid satu. Edisi kesepuluh. Jakarta: Erlangga

Tjiptono, Fandy. 2008. Strategi Pemasaran. Edisi 3, Andi: Yogyakarta 